\title{
Gender xenophobia: candidate gender behavior in a love and preliminary period
}

\author{
Ivan Svyatnenko, Classical Private University
}

The article is devoted to the study of scenarios of gender behavior in situations of violence, gender patterns of friendship / maintenance of horizontal relations after marriage by representatives of men and women, tolerance / intolerance towards minority gender representatives, gender maturity / separation and heterophobia in marriage and gender legitimization of male friendship and women.

This topic is relevant in the context of the study of gender hierarchies and latent discriminatory practices regarding men in matriarchal gender culture. The subject matter of the article is actualized, first and foremost, in connection with the social consequences of applying double standards of evaluation and violations of gender justice and equality arising from gender racism.

The attitude of men and women in Ukraine to the gender standards of friendship with representatives of the sexes, as well as the attitude towards minority gender representatives, can be generalized using the concept of gender xenophobia. This concept allows you to analyze the empirical research of women's ambitions regarding male friendship (as well as the slight discovery of the relevant crimes and expectations of men about women's friendship) in the context of understanding gender identity. The functional link between gender xenophobia and gender identity is considered in the visual analysis and sociology of visual symbolism, taking into account the following key ideas: a) xenophobia sets the bias of women's gender consciousness on the basis of the opposition «we-them», «theirs-aliens», using distrust, fear, hatred of «strangers» as the basis of group communication, integration and consolidation of actions for the implementation of group gender repression against men; b) the essential characteristics of matriarchal gender xenophobia are binary oppositions in the design of gender relations (high / low, significant / insignificant, etc.) and the structural evaluation of feminized men as «their», and masculinized men and representatives of minority gender groups - as «strangers»; c) the negative attitude of masculinized men and representatives of minority gender groups to «strangers» is significantly higher (by comparison with the male part of the sample) from the part of the female respondents; The basis of gender xenophobia, both for men and women, can be the affections of fear, anger, disgust, contempt, and envy; d) hostility towards masculinized men and representatives of minority gender groups as «alien» can be manifested in various hidden-aggressive actions towards identified «alien» not only in situations of real deviant behavior, but also in its absence; e) Generation of negative social feelings of women towards men can be caused by any situation of male friendship, which is automatically stigmatized as latent-homosexual and requiring control, mediation and regulation by women; e) the corresponding stereotypes of deviance of male friendship in the Ukrainian gender culture can be applied in the process of gender socialization by inducing homophobia to men who, on the basis of the suggestion of fear, disgust, shame, turn into the actual identification of male friendly relations as deviant (or questionable, normal), and women's friendly relations - both natural and legitimized in gender morals; g) hostility towards manhood as an identified «alien» is constructed with the help of social morality, gender mythology, religion and part of scientific or quasi-scientific ideas.

Keywords: gender scenarios; gender homophobia; gender heterophobia; gender xenophobia; minority gender communities

\section{Гендерна ксенофобія: сценарії гендерної поведінки в шлюбний і дошлюбний період}

Іван Святненко, Класичний приватний університет

Статтю присвячено дослідженню сценаріїв гендерної поведінки в ситуаціях насильства, гендерних сценаріїв дружби / підтримання горизонтальних відносин після вступу в шлюб представниками чоловічої та жіночої статі, толерантності / інтолерантності щодо представників міноритарних гендерних груп, оцінці гендерного злиття / сепарації та гетерофобії в шлюбі та гендерної легітимізації дружби чоловіків та жінок.

Зазначена тема є актуальною в контексті дослідження гендерних ієрархій та латентних дискримінаційних практик щодо чоловіків в умовах матріархальної гендерної культури. Тематика статті актуалізується перш за все у зв'язку із соціальними наслідками, що мають місце через застосування подвійних стандартів оцінювання та порушення гендерної справедливості і рівності, що випливає із гендерного расизму. 
Ставлення чоловіків та жінок в Україні до гендерних стандартів дружби із представниками своєї статі, а також ставлення до представників міноритарних гендерних груп може бути узагальненим із використанням концепції гендерної ксенофобії. Ця концепція дозволяє аналізувати виявлені в емпіричному дослідженні владні амбіції жінок щодо чоловічої дружби (як і незначну виявленість відповідних кратичних домагань та очікувань чоловіків щодо жіночої дружби) в контексті розуміння гендерної ідентичності. Функціональний зв'язок гендерної ксенофобії та гендерної ідентичності розглядається в візуальній аналітиці та соціології візуального символізму з урахуванням наступних ключових ідей: а) ксенофобія задає упередження гендерної свідомості жінок на основі опозиції «ми - вони», «свої - чужі», використовуючи недовіру, страх, ненависть до «чужих» як основу групової комунікації, інтеграції та консолідації дій щодо реалізації групової гендерної репресії щодо чоловіків; б) сутнісними характеристиками матріархальної гендерної ксенофобії виступають бінарні опозиції в конструюванні гендерних відносин (високе / низьке, значуще / незначуще тощо) та структурної оцінки фемінізованих чоловіків як «своїх», а маскулінізованих чоловіків та представників міноритарних гендерних груп - як «чужих»; в) з боку жіночої частини респондентів виявляється істотно вищий (у порівнянні $з$ чоловічою частиною вибірки) негативізм у ставленні до маскулінізованих чоловіків та представників міноритарних гендерних груп як до «чужих»; основою гендерної ксенофобії як чоловіків, так і жінок можуть бути афекти страху, гніву, відрази, презирства та заздрості; г) ворожість по відношенню до маскулінізованих чоловіків та представників міноритарних гендерних груп як до «чужих» може виявлятися в різноманітних приховано-агресивних діях по відношенню до ідентифікованих «чужим» не тільки в ситуаціях реальної девіантної поведінки, але і ії відсутності; д) згенеровування негативних соціальних почуттів жінок щодо чоловіків може спричинятися будь-якими ситуаціями чоловічої дружби, яка автоматично стигматизується як латентно-гомосексуальна і така, що потребує контролю, опосередковування та регулювання з боку жінок; є) відповідні стереотипи девіантності чоловічої дружби в українській гендерній культурі можуть насаджуватися в процесі гендерної соціалізації шляхом навіювання гомофобії чоловікам, які на основі сугестії настанов страху, відрази, сорому, переростають у фактичне ототожнення чоловічих дружніх відносин як девіантних (або сумнівно-нормальних), а жіночих дружніх відносин - як природних і легітимізованих в гендерній моралі; ж) ворожість по відношенню до чоловічості як ідентифікованої «чужої» конструюється за допомогою соціальної моралі, гендерної міфології, релігії та частини наукових або квазінаукових уявлень.

Ключові слова: гендерні сченарії; гендерна гомофобія; гендерна гетерофобія; гендерна ксенофобія; міноритарні гендерні спільноти

\section{Гендерная ксенофобия: сценарии гендерного поведения в брачный и добрачный период}

\section{Святненко Иван, Классический приватный университет}

Статья посвящена исследованию сценариев гендерного поведения в ситуациях насилия, гендерных сценариев дружбы / поддержания горизонтальных отношений после вступления в брак представителями мужского и женского пола, толерантности / интолерантности в отношении представителей миноритарных гендерных групп, оценке гендерного слияния / сепарации и гетерофобии в браке и гендерной легитимизации дружбы мужчин и женщин. Указанная тема является актуальной в контексте исследования гендерных иерархий и латентных дискриминационных практик в отношении мужчин в условиях матриархальной гендерной культуры. Тематика статьи актуализируется прежде всего в связи с социальными последствиями, которые имеют место из-за применения двойных стандартов оценки и нарушения гендерной справедливости и равенства, следует из гендерного расизма. Отношение мужчин и женщин в Украине в гендерных стандартах дружбы с представителями своего пола, а также отношение к представителям миноритарных гендерных групп может быть обобщенным с использованием концепции гендерной ксенофобии. Эта концепция позволяет анализировать выявленные в эмпирическом исследовании властные амбиции женщин насчет мужской дружбы (как и незначительную выявляемость соответствующих кратических притязаний и ожиданий мужчин относительно женской дружбы) в контексте понимания гендерной идентичности. Функциональная связь гендерной ксенофобии и гендерной идентичности рассматривается в визуальной аналитике и социологии визуального символизма с учетом следующих ключевых идей: а) ксенофобия задает предвзятость гендерного сознания женщин на основе оппозиции «мы - они», «свои - чужие», используя недоверие, страх, ненависть к «чужим» как основу групповой коммуникации, интеграции и консолидации действий по реализации группового гендерной репрессии 
в отношении мужчин; б) сущностными характеристиками матриархальной гендерной ксенофобии выступают бинарные оппозиции в конструировании гендерных отношений (высокое / низкое, значимое / незначительное т.д.) и структурной оценки феминизированных мужчин как «своих», а маскулинизированных мужчин и представителей миноритарных гендерных групп - как «чужих»; в) со стороны женской части респондентов оказывается существенно выше (по сравнению с мужской частью выборки) негативизм в отношении к маскулинизированным мужчинам и представителям миноритарных гендерных групп как к «чужим»; основой гендерной ксенофобии как мужчин, так и женщин могут быть аффекты страха, гнева, отвращения, презрения и зависти; г) враждебность по отношению к маскулинизированным мужчинам и представителям миноритарных гендерных групп как к «чужим», может проявляться в различных скрыто-агрессивных действиях по отношению к идентифицированных «чужим» не только в ситуациях реальной генерирование негативных социальных чувств женщин в отношении мужчин может вызываться любыми ситуациями мужской дружбы, которая автоматически стигматизируется как латентно-гомосексуальная и такая, которая требует контроля, опосредствования и регулирования со стороны женщин; е) соответствующие стереотипы девиантности мужской дружбы в украинской гендерной культуре могут насаждаться в процессе гендерной социализации путем внушения гомофобии мужчинам, которые, на основе суггестии установок страха, отвращения, стыда, перерастают в фактическое отождествление мужских дружеских отношений как девиантных (или сомнительно-нормальных), а женских дружеских отношений - как естественных и легитимизированных в гендерной морали; ж) враждебность по отношению к мужественности как идентифицированной «чужой» конструируется с помощью социальной морали, гендерной мифологии, религии и части научных или квазинаучных представлений.

Ключевые слова: гендерные сценарии; гендерная гомофобия; гендерная гетерофобия; гендерная ксенофобия; миноритарные гендерные сообщества

\section{Relevance of research.}

7 he article is devoted to the study of scenarios of gender behavior in situations of violence, gender patterns of friendship / maintenance of horizontal relations after marriage by representatives of men and women, tolerance / intolerance towards minority gender representatives, gender maturity / separation and heterophobia in marriage and gender legitimization of male friendship and women.

This topic is relevant in the context of the study of gender hierarchies and latent discriminatory practices regarding men in matriarchal gender culture. The subject matter of the article is actualized, first and foremost, in connection with the social consequences of applying double standards of evaluation and violations of gender justice and equality arising from gender racism.

The purpose and objectives of the article. The purpose of the article is to build an empirical description of the structuring of gender behavior patterns in the area of measuring violence and informal communication between men and women. The objectives of the article are: 1) to empirically verify the hypothesis of empirical research, in accordance with which: a) men will treat women with physical violence more tolerant and more restrained in their estimates of female violence than women; b) Horizontal male communication after marriage is more likely to undergo transformation in the direction of their full / partial blocking and limitation in space and time on the part of women www.grani.org.ua than the corresponding communication of women by men; c) regarding minority groups is generally intolerant; d) the matriarchal organization of the family, in which a woman acts as the center of power and husbandman of time, shifts the structuring possibilities of indirect influence on the friendly relations of men with men towards women. 2) build, on the basis of hypothesis verification, the empirical characterization of the structuring of gender behavior scenarios in the area of assessment of violence and informal communication between men and women.

An analysis of recent research and publications in which the scientific problem was initiated.

Explanation of the relevant manifestations of gender xenophobia has been made in an author's empirical study, which is fundamentally based on the concepts of matriarchal heterophobia and male induced homophobia. The term «heterophobia» in the discourse of gender sociology denotes the hidden hostility or discrimination of people with heterosexual orientation $[4 ; 6 ; 10]$.

In previous publications of the author, proof of transfiguration homosexuality in the Ukrainian gender culture has been proven. It is transfigurative homosexuality that becomes the basis for heterophobia as the hidden discrimination of men by women on the basis of their traditional gender orientation and involves experiencing persistent social feelings of fear / aversion to masculine heterosexuals. 
Underlying heterophobia is the ideology of radical left-wing feminism, presented in the writings of F. Engels, H. Astrid, S. Brown, B. Ehrenreich, B. Friedman, M. Heisworth, G. Spivak [1-3; 5-7; 10]. Authors define this concept as the fear of homosexuals in relation to heterosexuals, although the author of this study believes that the concept of heterophobia conceptualizes not only the expression of fear in a sexual but in the broader context of gender identity.

Heterophobia is also conceptualized in the monograph by two authors, «Does anyone ever remember when sex brought pleasure?» (Does Anyone Still Remember When Sex Was Fun?). The monograph is devoted to the problems of sexual frustration in American society. The authors of the monograph consider it logical to increase homophobia through the intensification of heterophobia, which, in our opinion, leads to the splitting of gender identity and internal gender conflict [4].

Significant for empirical research and verification of its hypotheses is the position regarding the complementarity of homophobia and heterophobia, which enables the use of cultural and social systemology to study the factors of gender relations.

In 1998, in Daphne Patay's article «Heterophobia: Sexual harassment and the future of feminism,» a gender heterophobia was suggested, which, according to the researcher, is the basis for the "production of sexual harassment» with the selfish aim of achieving gender power [9].

Presentation of the main material of the article. The evaluation of the results of the empirical study on question 6 provides an opportunity to assess the attitude of respondents from both sexes to the assessment of the physical violence of men to women and women to men. According to the hypothesis, men will treat women with physical violence more tolerant and more restrained in assessing women's violence towards themselves than women.

Women are expected to assess male aggression as being immoral in more than one percent of cases, rather than the opposite (male respondents are more likely to take a woman-centered position rather than approving, rather than approving, physical violence against women. On the other hand, women will be more likely than men to demand from men significantly higher restraint.

The data of an empirical study make it possible to verify this hypothesis. It appears from Table 1 that the overwhelming majority of men $(64 \%)$ are in positions of ethical tolerance of female violence, or it justifies physical aggression on the part of women, motivating it as a natural weakness.

On the other hand, only $10 \%$ of male respondents feel that women are being morally restrained as regards male aggression, although $20 \%$ of male respondents still suggest physical violence.

The synthesis of the results of the answers to question 7 is indicative of gender-based friendship / maintenance of horizontal relations after marriage by male and female representatives. The content of the hypothesis in question 8 related to the fact that the horizontal communication of men after marriage is more likely to undergo transformation in the direction of their complete / partial blocking and restriction in space and time.

An additional hypothesis was the assumption that, given the maintenance of horizontal communication between men, women tend to become more often mediated by the presence of women than women: women's communication is less frequent than men, mediated by the presence of men. The second additional hypothesis was the assumption about the mediation of horizontal communication between men by the presence of women, interpreted as «family friendship».

Under these circumstances, during the communication of men, women censor the content of their communication through expressive expressions. The statements contain, as a rule, emotional approval or condemnation of certain orthogonal statements (those, texts) of men. All the aforementioned hypotheses (both primary and secondary) have been verified.

Only $14 \%$ of female respondents consider it normal to preserve previous relationships with their male friends after marriage. More than half of female respondents $(61 \%)$ consider it necessary to terminate relations between male friends, limit them in time or «allow» men to communicate in the presence of women (the format of «family communication»).

At the same time, only a quarter $(25 \%)$ of male respondents consider it necessary to stop or restrict pre-marital friendship between female friends. On the other hand, among the male respondents, the number of those who exceeds the number of adherents of the invariability of the friendly relations between women after the marriage is $35 \%$, which is $20 \%$ more compared to the number of adherents of male friendship after marriage in the female section of the sample.

Due to such an evaluative attitude and the presence of double standards in relation to male and female friendship, erosion of horizontal communications is occurring and mutual distrust 
and hidden gender hostility within the male community are increasing. It ceases to function just as a community, its processes of fragmentation

/ atomization intensify. Interrupted, fragmented communications not only do not promote trust, but also create the appropriate barriers.

Table 1. Question 6. Imagine that you have witnessed the following situation. Unknown to you, a man and a woman quarrel with each other in a public place, accompanied by screams, images, thumbs and cuffs. Identify an acceptable assessment of the situation of the man and woman. (Choose only one answer option)

\begin{tabular}{|c|c|}
\hline \multicolumn{2}{|c|}{ ANSWERS POSSIBLE } \\
\hline \multicolumn{2}{|c|}{$\begin{array}{l}\text { 6.1. Behavior of both parties is quite normal to each other, since this conflict, } \\
\text { both male and female, behave in a way familiar to such situations. }\end{array}$} \\
\hline MEN, \% & WOMEN, \% \\
\hline 6 & 2 \\
\hline \multicolumn{2}{|c|}{$\begin{array}{l}\text { 6.2. A man in such situations should behave restraint, tolerate, not to assume the } \\
\text { woman as a verbal aggression, and physical actions. }\end{array}$} \\
\hline MEN, $\%$ & WOMEN, \% \\
\hline 38 & 48 \\
\hline \multicolumn{2}{|c|}{$\begin{array}{l}\text { 6.3. A woman can commit any man's aggressive actions, since she is weaker and } \\
\text { is allowed. }\end{array}$} \\
\hline MEN, \% & WOMEN, \% \\
\hline 26 & 32 \\
\hline \multicolumn{2}{|c|}{$\begin{array}{l}\text { 6.4. In such situations, a woman must behave with restraint, tolerate, and do not } \\
\text { assume men's verbal aggression, and physical actions. }\end{array}$} \\
\hline MEN, \% & WOMEN, \% \\
\hline 10 & 10 \\
\hline \multicolumn{2}{|c|}{$\begin{array}{l}\text { 6.5. A man can commit any act of aggression against a woman, because he is } \\
\text { stronger, and therefore the woman must realize it. }\end{array}$} \\
\hline MEN, \% & WOMEN, \% \\
\hline 20 & 10 \\
\hline
\end{tabular}

It is clear that the imposition of such restrictions pursues political goals in itself and not only fosters gender racism, but also serves the seclusion of men and the blocking of their gender solidarity. For women, such a stratagem structuring of male relationships can be winning in several respects. First, it brings benefits in terms of community support and manifestations of women's solidarity, which contributes to the effectiveness of group mobing and ostracism practices in communities that enable such behavior.

Secondly, the fragmentation of male communication in itself can be the reason for their complete cessation. Consequently, women have the opportunity at the expense of moral pressure to first restrict communication between men, and then www.grani.org.ua promote a complete break of the relationship between them, motivating it «inappropriate relationships», «unsuccessful friendship,» and so on.

Homogenizing devices are becoming an additional political gain for women, which are easily instilled and formed in relation to distant and littleknown objects. Cultivation of homophobia is carried out by women in relation to men partly on the basis of double standards of tactile homoelectric assessment (already mentioned in previous publications). Negatively-expressive accompaniment of such manifestations of male behavior contributes to the development of men's penetration fears.

On the other hand, the key factor of homophobia is the defectization of the value consciousness of 
men. Creation of defective value consciousness as a process is carried out through management of men's time and reorientation of men in those cases where they show interest in the themes and problems of religion, philosophy, ideology, psychology, sociology, etc. spheres of value, theoretical and practical knowledge, the achievement of which can put women in doubt.

Consequently, double standards for assessing male and female friendship can be considered as manifestations of gender racism, and their implementation - has a destructive effect not only on the level of microcommunications, but also on the institutional architectural structure of society. After all, the value-programming component of the latter is male solidarity, especially if one takes into account the social fact of the prevalence of men in power structures, the propaganda system, big business and other system-providing macrostructures.

How should men and women's relationships with friends (friends) change sex with one another after marriage?

(Choose only one answer option).

\begin{tabular}{|c|c|c|c|}
\hline \multicolumn{4}{|c|}{ ANSWERS POSSIBLE } \\
\hline \multicolumn{2}{|c|}{$\begin{array}{c}\text { Relationships of men with friends of one sex } \\
\text { (other men) after marriage }\end{array}$} & \multicolumn{2}{|c|}{$\begin{array}{c}\text { Relationships of women with friends of one } \\
\text { sex (other men) after marriage }\end{array}$} \\
\hline \multicolumn{2}{|c|}{$\begin{array}{l}\text { 1. Relations with former friends should be } \\
\text { discontinued. After all, now the husband has a } \\
\text { family, and friends must stay in the past }\end{array}$} & \multicolumn{2}{|c|}{$\begin{array}{l}\text { 1. Relations with former girlfriends should } \\
\text { be discontinued. After all, now a woman has } \\
\text { a family, and friends must stay in the past }\end{array}$} \\
\hline $\begin{array}{c}\text { MEN,\% } \\
23\end{array}$ & $\begin{array}{l}\text { WOMEN, \% } \\
34\end{array}$ & $\begin{array}{c}\text { MEN, \% } \\
10\end{array}$ & $\begin{array}{l}\text { WOMEN, \% } \\
6\end{array}$ \\
\hline \multicolumn{2}{|c|}{$\begin{array}{l}\text { 2. Relations with former friends should be } \\
\text { limited in time and supported by the consent of } \\
\text { the woman. After all, now the husband has a } \\
\text { family, and she is more important than } \\
\text { friendship }\end{array}$} & \multicolumn{2}{|c|}{$\begin{array}{l}\text { 2. Relations with former girlfriends should } \\
\text { be limited in time and maintained with the } \\
\text { consent of the husband. After all, women } \\
\text { now have a family, and they are more } \\
\text { important than friendship }\end{array}$} \\
\hline $\begin{array}{c}\text { MEN,\% } \\
14\end{array}$ & $\begin{array}{l}\text { WOMEN, \% } \\
27\end{array}$ & $\begin{array}{c}\text { MEN,\% } \\
15\end{array}$ & $\begin{array}{l}\text { WOMEN, \% } \\
6\end{array}$ \\
\hline \multicolumn{2}{|c|}{$\begin{array}{l}\text { 3. Relations with former friends can be } \\
\text { supported by the friendship of families when } \\
\text { women mediate / participate in communicating } \\
\text { with each other and communicate with one } \\
\text { another }\end{array}$} & \multicolumn{2}{|c|}{$\begin{array}{l}\text { 3. Relations with former friends can be } \\
\text { supported by the friendship of families when } \\
\text { women mediate / participate in } \\
\text { communicating with each other and } \\
\text { communicate with one another }\end{array}$} \\
\hline $\begin{array}{c}\text { MEN, \% } \\
38\end{array}$ & $\begin{array}{l}\text { WOMEN, \% } \\
25\end{array}$ & $\begin{array}{l}\text { MEN, \% } \\
40\end{array}$ & $\begin{array}{l}\text { WOMEN, \% } \\
26\end{array}$ \\
\hline \multicolumn{2}{|c|}{$\begin{array}{l}\text { 4. Relations with former friends should remain } \\
\text { in the same form as they did before marriage } \\
\text { and should not vary in any respect }\end{array}$} & \multicolumn{2}{|c|}{$\begin{array}{l}\text { 4. Relations with former girl-friends should } \\
\text { remain in the same form as they did before } \\
\text { marriage and should not vary in any respect }\end{array}$} \\
\hline $\begin{array}{c}\text { MEN,\% } \\
25\end{array}$ & $\begin{array}{c}\text { WOMEN, \% } \\
14\end{array}$ & $\begin{array}{l}\text { MEN, \% } \\
35\end{array}$ & $\begin{array}{l}\text { WOMEN, \% } \\
66\end{array}$ \\
\hline
\end{tabular}

Summarizing the results of the answers to question 8, one can assess gender tolerance / intolerance with respect to minority gender groups (gay, bisexual, lesbian, prostitute). The highest rates of intolerance are gay, lesbian and bisexual $(52 \%$ and $54 \%, 54 \%$ and $58 \%$ respectively, and $74 \%$ and $51 \%$, respectively, among men and women), the lowest are prostitutes (21\% and 35\% respectively).

On the other hand, attention is drawn to the intolerant attitude of female respondents to prostitutes as compared to male respondents, which is explained by the predominance of domestic and shadow prostitution over the legal one. In Ukraine, women who are part of the criminal-shadow market 
of sex services are contingents that are exploited by the security forces.

The latter receive corrupt rent from prostitutes and therefore are interested in shadowing this group of people. At the same time, the relevant lobby groups in the authorities, with the assistance of the media, constantly reproduce in the mass media the unwillingness of the Ukrainian society to legalize prostitution.

At the same time, respondents (as well as female respondents) are more likely to be tolerant of lesbian and prostitute tolerance. $54 \%$ of male respondents consider it possible to come out for prostitutes. On the other hand, only $27 \%$ of such women are

found among women, which gives grounds to speak about the unequal estimation of the legalization of prostitution among the two unemployed sexdemographic groups.

As a result, it can be stated that in general less tolerant attitude of male respondents towards minority gender groups of men (gays and bisexuals) and more tolerant attitude towards minority gender groups of women (lesbians and prostitutes). These results are explained by gender matriarchal racism, which by default supports the idea of superiority of women in relation to men, and hence the greater acceptability of female deviations compared to men.

Table 3. Question 8.

Define your attitude towards minority gender representatives (gay, bisexual, lesbian, prostitutes) (Select only one answer option by ticking the answer number in the corresponding cell with the gender group).

\begin{tabular}{|c|c|c|c|c|c|c|c|}
\hline \multicolumn{8}{|c|}{$\begin{array}{l}\text { 8.1. Representatives of these groups should hide their belongings and be } \\
\text { ashamed of it. But their membership in these groups can not be the basis for } \\
\text { moral condemnation, bringing to legal liability and restriction in any rights }\end{array}$} \\
\hline \multicolumn{4}{|c|}{$M E N, \%$} & \multicolumn{4}{|c|}{ WOMEN,\% } \\
\hline Gay & Lesbians & Bisexual & Frost & Gay & Lesbians & Bisexual & Frost \\
\hline 45 & 18 & 21 & 25 & 36 & 14 & 23 & 36 \\
\hline \multicolumn{8}{|c|}{$\begin{array}{l}\text { 8.2. Representatives of these groups can openly declare their affiliation and do not } \\
\text { be ashamed of it. They can be allowed to hold various public events, openly gather } \\
\text { in public places, and also equalize them in rights with other groups of the } \\
\text { population. }\end{array}$} \\
\hline \multicolumn{4}{|c|}{$M E N, \%$} & \multicolumn{4}{|c|}{ WOMEN,\% } \\
\hline $\begin{array}{c}\text { Gay } \\
3\end{array}$ & $\begin{array}{c}\text { Lesbian } \\
28\end{array}$ & $\begin{array}{c}\text { Bisexual } \\
5\end{array}$ & $\begin{array}{c}\text { Frost } \\
54\end{array}$ & $\begin{array}{c}\text { Gay } \\
10\end{array}$ & $\begin{array}{c}\text { Lesbians } \\
28\end{array}$ & $\begin{array}{c}\text { Bisexual } \\
16\end{array}$ & $\begin{array}{c}\text { Frost } \\
27\end{array}$ \\
\hline \multicolumn{8}{|c|}{$\begin{array}{l}\text { 8.3. Representatives of these groups should hide their belongings and be ashamed } \\
\text { of it. They, if they admit to belonging to these groups, should be subjected to moral } \\
\text { censure, to be brought to legal liability and in every possible way to restrict all } \\
\text { rights. }\end{array}$} \\
\hline \multicolumn{4}{|c|}{$M E N, \%$} & \multicolumn{4}{|c|}{ WOMEN,\% } \\
\hline Gay & Lesbian & Bisexual & Frost & Gay & Lesbians & Bisexual & Frost \\
\hline 52 & & & & 54 & & & 35 \\
\hline
\end{tabular}

The synthesis of the results of the answers to question 9 makes it possible to assess the indicators of heterophobia and attitudes towards same-sex communication by men and women in the form of male and female friendship. These indicators are part of the gender scenarios and allow, in addition to the identified indicators, to assess the relevant claims for the merger / separation of family 
members with each other, having identified the center of family power and evaluating the relevant intentions to restrict horizontal communications. The results of the responses give the possibility of an indirect assessment of the inversion of gender identity (manifestations of latent transfiguration homosexuality).

The obtained data allow us to verify the hypothesis of the study according to which the matriarchal organization of the family, in which the woman acts as the center of power and man's manager, shifts the structural possibilities of indirect influence on the friendly relations of men and men towards women. At the same time, it is common practice for men to maintain women's horizontal communications with friends in a time convenient for women and in an acceptable time frame. On the other hand, for women, there is more typical behavior with the elements of regulating the time and scope of communication between men and one another.

The answer variants are placed on a conventional scale from a neutral attitude (Option 1: Admissibility of regular parallel relations with another man / woman (men / women) to open-ended jealousy and heterophobia (Option 5).

Intermediate forms of social behavioral responses, which are indicators of heterophobic growth, are a statement of the experience of accompanying internal tension (option 2), the use of indirect methods of psychological pressure: persuasion, emotional influence, etc.)) (option 3) or direct methods of psychological pressure (blackmail, threats ) (option 4).

From the data it becomes apparent that only $18 \%$ of male respondents find heterophobic attitudes toward women's friendship. The vast majority of male respondents $(53 \%)$ perceive the parallel communication of their wives / friends with their former girlfriends as normal and customary.

On the other hand, only $7 \%$ of women respondents believe that the situation of communication between men and friends is quite permissible and should not interfere in any way. According to research data, $69 \%$ of women respondents are heterophobic, while $38 \%$ of women believe that male friendship has homosexual implications and $21 \%$ are ready to resort to indirect or direct pressure in order to block or interrupt such communications.

Regulation of the friendship of men through not only time management, but also using methods of emotional pressure, blackmail, intimidation and threats can be considered as components of the moral and pedagogical power of women in the matriarchal family.

This moral and pedagogical authority is intensified by appropriate new developments in the existing criminal law, in particular - in the Law of Ukraine "On Prevention and Combating Domestic Violence». Articles 25-28 define only the person as the subject of a crime (in the designated articles the term "offender» appears and there is no term "offender» that automatically excludes women from the range of subjects of domestic violence).

Conclusions The attitude of men and women in Ukraine to the gender standards of friendship with representatives of the sexes, as well as the attitude towards minority gender representatives, can be generalized using the concept of gender xenophobia. This concept allows you to analyze the empirical research of women's ambitions regarding male friendship (as well as the slight discovery of the relevant crimes and expectations of men about women's friendship) in the context of understanding gender identity. The functional link between gender xenophobia and gender identity is considered in the visual analysis and sociology of visual symbolism, taking into account the following key ideas: a) xenophobia sets the bias of women's gender consciousness on the basis of the opposition «wethem», «theirs-aliens», using distrust, fear, hatred of «strangers» as the basis of group communication, integration and consolidation of actions for the implementation of group gender repression against men; b) the essential characteristics of matriarchal gender xenophobia are binary oppositions in the design of gender relations (high / low, significant / insignificant, etc.) and the structural evaluation of feminized men as «their», and masculinized men and representatives of minority gender groups - as «strangers»; c) the negative attitude of masculinized men and representatives of minority gender groups to «strangers» is significantly higher (by comparison with the male part of the sample) from the part of the female respondents; The basis of gender xenophobia, both for men and women, can be the affections of fear, anger, disgust, contempt, and envy; d) hostility towards masculinized men and representatives of minority gender groups as «alien» can be manifested in various hidden-aggressive actions towards identified «alien» not only in situations of real deviant behavior, but also in its absence; e) Generation of negative social feelings of women towards men can be caused by any situation of male friendship, which is automatically 
stigmatized as latent-homosexual and requiring control, mediation and regulation by women; e) the corresponding stereotypes of deviance of male friendship in the Ukrainian gender culture can be applied in the process of gender socialization by inducing homophobia to men who, on the basis of the suggestion of fear, disgust, shame, turn into

the actual identification of male friendly relations as deviant (or questionable, normal), and women's friendly relations - both natural and legitimized in gender morals; g) hostility towards manhood as an identified «alien» is constructed with the help of social morality, gender mythology, religion and part of scientific or quasi-scientific ideas.

Table 4. Question 9. Imagine that the husband (or woman) with whom (or with whom) you are married, maintains regular relationships with friends (friends). From the options below, choose the one that most closely matches your assessment of the situation and the corresponding actions in it.

\begin{tabular}{|c|c|}
\hline WOMEN ON MEN & MEN OF WOMEN \\
\hline $\begin{array}{l}\text { 9.1.1. This situation is quite acceptable. I will } \\
\text { not interfere in communication in any way } \\
\text { (in \%) }\end{array}$ & $\begin{array}{l}\text { 9.1.2. This situation is quite acceptable. I will } \\
\text { not interfere in communication in any way } \\
\text { (in \%) }\end{array}$ \\
\hline 7 & 53 \\
\hline $\begin{array}{l}\text { 9.1.2. Such a situation, although permissible, } \\
\text { will cause internal stress for me (in } \%) \text {. }\end{array}$ & $\begin{array}{l}\text { 9.2.2. Such a situation, although permissible, } \\
\text { will cause internal stress for me (in } \% \text { ). }\end{array}$ \\
\hline 18 & 12 \\
\hline $\begin{array}{l}\text { 9.1.3. Such a situation, although permissible, } \\
\text { will cause an internal tension for me, and I will } \\
\text { indirectly (through persuasion, emotional } \\
\text { influence, etc.) interfere with this (in \%). }\end{array}$ & $\begin{array}{l}\text { 9.2.3. Such a situation, although permissible, } \\
\text { will cause an internal tension for me, and I will } \\
\text { indirectly (through persuasion, emotional } \\
\text { influence, etc.) interfere with this (in } \% \text { ). }\end{array}$ \\
\hline 24 & 9 \\
\hline $\begin{array}{l}\text { 9.1.4. Such a situation, although permissible, } \\
\text { will cause internal tensions for me. I will be } \\
\text { actively interrupted by direct ways (through } \\
\text { threats, intimidation, blackmail, etc.), because I } \\
\text { find this communication in a marriage } \\
\text { inappropriate. After all, such relationships } \\
\text { often occur on the basis of non-traditional } \\
\text { sexual orientation of men (in } \% \text { ). }\end{array}$ & $\begin{array}{l}\text { 9.2.4. Such a situation, although permissible, } \\
\text { will cause internal tensions for me. I will be } \\
\text { actively interrupted by direct ways (through } \\
\text { threats, intimidation, blackmail, etc.), because I } \\
\text { find this communication in a marriage } \\
\text { inappropriate. After all, such relationships } \\
\text { often occur on the basis of non-traditional } \\
\text { sexual orientation of men (in } \% \text { ). }\end{array}$ \\
\hline 27 & 11 \\
\hline $\begin{array}{l}\text { 9.1.5. This situation will cause internal tension } \\
\text { to me because of the jealousy that I will endure } \\
\text { in connection with the friendly relations of } \\
\text { men. After all, the only friend of the husband } \\
\text { in marriage is his wife (y \%). }\end{array}$ & $\begin{array}{l}\text { 9.2.5. This situation will cause internal tension } \\
\text { to me because of the jealousy that I will endure } \\
\text { in connection with the friendly relations of } \\
\text { WOMEN, After all, the only friend of a } \\
\text { woman in marriage is her husband (in } \% \text { ). }\end{array}$ \\
\hline 24 & 15 \\
\hline
\end{tabular}

Note. If you are a man, then choose the options for the right column (for women), if the woman is left (for men). In this case, please select only one of the answer options. 


\section{REFERENCES}

1. Jengel's, F. (1981). Proishozhdenie sem'i, chastnoj sobstvennosti i gosudarstva [The origin of the family, private property and the state]. K. Marks i F. Jengel's. Izbrannye proizvedenija. Moscow: Gospolitizdat [in Russian].

2. Henry, A. (2004). Not my mother's sister: generational conflict and third-wave feminism. Bloomington: Indiana University Press.

3. Brown, S. (1996). Beyond Feminism: Anarchism and Human Freedom. Anarchist Papers, 3, 124-133. Sydney: Black Rose Books.

4. Anderson, P.B., Mauro, D.De, \& Noonan, R.J. (Eds.). (1990). Does Anyone Still Remember When Sex Was Fun? Positive Sexuality in the Age of AIDS. Published by Kendall Hunt Pub Co

5. Ehrenreich, B. (1976). What is Socialist Feminism? Retrieved from: https://www.marxists.org/subject/women/ authors/ehrenreich-barbara/socialist-feminism.htm

6. Freedman, E.B. (2003). No Turning Back: The History of Feminism and the Future of WOMEN. Ballantine Books.

7. Hawkesworth, M.E. (2006). Globalization and Feminist Activism. Rowman \& Littlefield.

8. Patai, D. (1998). Heterophobia: Sexual Harassment and the Future of Feminism. Washington: Rowman \& Littlefield Publishers

9. Spivak, G.C. (1981). «French Feminism in an International Frame». Yale French Studies, 62, 154-184.

\section{Святненко Іван Олександрович}

Докторант

Класичний приватний університет

69002, м. Запоріжжя, вул. Жуковського, 70Б

\section{Svyatnenko Ivan}

Doctoral student

Classical Private University

70B, Zhukovskoho Str., Zaporizhzhia, 69002, Ukraine

Email: magellan4x4@ukr.netＯRCID: 0008-0006-5896-6273

Цитування: Святненко I. О. Гендерна ксенофобія: кандидат гендерної поведінки в любові і попередньому періоді / І. О. Святненко // Науково-теоретичний альманах «Грані». - 2019. - Т. 22. - № 3. C. 85-94.

Citation: Svyatnenko, I.O. (2019). Gender xenophobia: candidate gender behavior in a love and preliminary period. Scientific and theoretical almanac «Grani», 22 (3), 85-94. 